\title{
Promoting extensive reading in a blended learning modality: Students' perceptions
}

\section{Promover la lectura extensiva en una modalidad de aprendizaje mixto: Percepciones de los estudiantes}

\author{
FLORES-GONZÁLEZ, Norma †* \\ Facultad de Lenguas, Benemérita Universidad Autónoma de Puebla \\ ID $1^{\text {er }}$ Autor: Norma, Flores-González /ORC ID: 0000-0002-4967-8854, Researcher ID Thomson: S-6917-2018, CVU \\ CONACYT ID: 957036
}

DOI: $10.35429 / J T E R .2019 .16 .5 .43 .54$

Received September 02, 2019; Accepted December 30, 2019

\begin{abstract}
Reading in foreign language is a difficult ability to foster and a boring task for some students. That is why teachers should look for attractive ways to promote it. The objective of this research is to characterize students' perceptions towards the use of a blended learning modality to promote extensive reading, as well as to know if they consider having meaningful reading comprehension when working with it at the Bachelor of Teaching English at the Benemerita Universidad Autonoma de Puebla. To analyze this phenomenon, a cross-sectional quantitative study was accomplished with a Likert-scale questionnaire and the TOEFL examination test as instruments. The results characterize the subjects' perceptions as identifying the blended learning modality like a suitable learning resource to promote extensive reading as well as another technology-based instructional delivery environment with special attributes that empower meaning reading-learning experiences since their tutor was available inside and outside the classroom to help them in their extensive reading process. Besides, they did extensive reading in shorter periods for specific purposes like pleasure, information, and general understanding. Finally, they found that working in this modality promotes cognitive processing if the tasks are pedagogically designed.
\end{abstract}

Extensive reading, Blended learning modality, Meaningful learning

\section{Resumen}

Leer en un idioma extranjero es una habilidad difícil de fomentar y una tarea aburrida para algunos estudiantes. Así, los maestros deben buscar formas atractivas para promoverlo. El objetivo de esta investigación es caracterizar las percepciones de los estudiantes en el uso de la modalidad de aprendizaje mixto para promover la lectura extensa, así como saber si consideran tener una comprensión significativa cuando trabajan en esta modalidad en la Licenciatura en Enseñanza de Inglés en la Benemérita Universidad Autónoma de Puebla. Para analizar este fenómeno, se realizó un estudio cuantitativo transversal con un cuestionario de escala Likert y examen TOEFL como instrumento. Los resultados identificaron la modalidad de aprendizaje mixto como un recurso de aprendizaje adecuado para promover la lectura extensa y un entorno de entrega de instrucción basado en la tecnología con atributos especiales que fortalecen el significado de las experiencias de lectura y aprendizaje, pues su tutor estaba disponible dentro y fuera del aula para ayudarles. También, se realizaron lecturas extensas en períodos de tiempo cortos para fines específicos como placer, información y comprensión general. Finalmente, se encontró que esta modalidad promueve un procesamiento cognitivo si las tareas están diseñadas pedagógicamente.

Lectura extensa, Modalidad de aprendizaje mixto, Aprendizaje significativo

Citation: FLORES-GONZÁLEZ, Norma. Promoting extensive reading in a blended learning modality: Students' perceptions. Journal of Teaching and Educational Research. 2019. 5-16: 43-54

\footnotetext{
* Correspondence of the Author: (norma-fg@ hotmail.com)

$\dagger$ Researcher contributing as first Author
} 


\section{Introduction}

Speaking foreign language like English is a process that requires different skills to speakers, such as oral, written, reading and listening abilities, especially if they are non-natives and are learning it as a foreign language. Besides, it should be taken into account that one of the most difficult skills to foster in a student is the reading skill and of course, the reading comprehension process since it requires not only to know vocabulary or grammatical structures but also to read between lines, code and decode what is written and apprehend what was read. In addition, knowing that extensive reading (ER) is an active, interactive and intentional process, teachers should take notice at the process in order to motive students, first of all, to read and later, do it extensively because in Mexico, the percentage of reading in Spanish is low; then, in English is even lower.

An example of this is the problem that is been faced at the Bachelor of Teaching English in the Faculty of Languages at the Benemerita Universidad Autonoma de Puebla (BUAP) where the percentage of practicing reading in English (not necessarily academically) is low. Additionally, students think in reading as a boring-difficult process and experience the necessity to develop strategies or innovative ways to promote reading in attractive and meaningful settings as well as extensive due to their bachelor's that demands them read considerably.

Regarding this problem, during 2018 a program was accomplished that have students read in a blended learning (BL) modality to encourage them to do extensive reading, focused on academic texts. Now that it has been applied for more than a year, it is crucial to know about students' perceptions towards this way of reading and learning, so that some decisions could be taken for the program.

Based on the previous information, the objective of this research is to know if the use of blended learning modality promotes extensive reading based on students' perceptions as well as to know if they consider having a meaningful reading comprehension when working with it at the Bachelor in Teaching English at the Benemerita Universidad Autonoma de Puebla. Taking into account the objective, two research questions arose:

\author{
Does blended learning modality promote \\ extensive reading?
}

Do subjects consider having meaningful reading comprehension when working in a blended learning modality?

According to the research questions, the following hypothesis arose in this study:

$\mathrm{H} 1$ : extensive reading is promoted in blended learning modality according to students' perceptions

$\mathrm{H} 2$ : When working in a blended learning modality to promote extensive reading, students have meaningful reading comprehension.

The study is worthy to be carried out due to these reasons:

It is convenient since it will be useful to know what happens with the extensive reading and the reading process by itself in a blended modality, which is an updated way of education in this century.

It is socially relevant in this time when in Mexico, according to INEGI (2018) $73.1 \%$ Mexicans read and 21.6\% comprehend only half of it.

Additionally, it will solve a practical problem that is to promote the reading process as well as the extensive reading in the Faculty of Language at BUAP.

Theoretically, it will also contribute to knowledge about the state of the art of reading and the framework of each variable in this specific context to characterize students' perceptions, and the possible association between variables to prove the hypotheses.

The present research is justified because it tries to analyze a real problem. Besides, it will help both students and teachers from that context to understand the phenomena and take decisions to solve the problem. Last but not least, it will provide important information to the field so that other teachers or researchers interested in this research could apply, reply, refute or corroborate it. 


\section{Literature Review}

For a long time, it has been said that reading should be one of the fastest means of receiving information and while this is true, it is also that it is the most abandoned media in these times. Much of this due to the difficulties that the reading process itself implies and its understanding for the reader. Moreover, trying to develop extensive reading is even a heavier task that both students and teachers must promote to satisfy globalization demands and studies in Higher education.

Before talking about extensive reading, it is necessary to define reading comprehension since to have extensive reading, it is a must to understand what is been read.

Sánchez as cited in Banda (2019) defines reading comprehension as a process that occurs through the assimilation and interpretation of the ideas that he extracts from the text, generating new knowledge when related to his previous knowledge.

\section{Extensive reading}

According to Day and Bamford (1998), ER in foreign language learning can be traced back to the 1920s. Then, it is not a new type of reading, but it is still in progress to be developed in both foreign language traditional and virtual classrooms. Extensive reading involves reading large quantities of material or longer readings for general understanding. (Renandya and Jacobs, 2002).

Widely accepted, there are ten essential principles to foster ER in a foreign language classroom (Day and Bamford, 2002):

1. Easy reading material

2. Availability of enough different readings in genres and topics

3. Freedom to select a book or reading

4. Read as much as possible

5. Read for pleasure, information, and general understanding

6. The only reward is to read

7. Rapid reading process

8. Reading is silent and individual first, and then, collaboratively shared

9. Teachers orient and guide their students.

10. Teachers are the reader's model.
These principles can be accomplished only if some strategies for reading comprehension and ER are used.

\section{Strategies to develop extensive reading}

Strategies are procedures used to regulate the activity of the reader within the process of reading comprehension, to the extent that its application allows the selection, evaluation, persistence or abandonment of certain actions to achieve understanding in big quantities.

Furthermore, cognitive structures also called thought patterns are mental processes that the reader uses to understand information. The level of reading comprehension depends a lot on the previous knowledge on the part of the reader and the non-visual information such as semantics, syntax, morphology, lexicology, coherence and cohesion, punctuation, and so on. However, the use of strategies for reading comprehension can help a lot in the understanding of the visual information (text) that is perceived by the eyes, since through the great variety of strategies, the meaning of the text is obtained and reading is understood, resulting in a reader with a high degree of comprehensive level in extensive reading.

On one side, taking into account Banda (2019), cognitive strategies of perception, attention, and memory during the pre-reading, while reading and post-reading stages could be adopted to flourish reading comprehension and extensive reading too.

On the other side, regarding McEwan (2007), there are seven strategies of highly effective readers, which can be used to encourage extensive reading. They are:

Activating. Use prior knowledge to get meaning from the text.

Inferring. Do some assumptions based on the reader's prior knowledge and what it is written in the text. is been read

Monitoring-Clarifying. Understand what

Questioning. Establishing dialogues with text (authors), classmates, and teachers 
Searching-Selecting. Search or share information to clarify misunderstandings, solve problems or gather information

Summarizing. Restating the meaning of text by paraphrasing

Graphic organizers. Graphic representation of the knowledge.

Besides, Day (2002) states that the virtuous circle of good extensive readers is to find strategies that allow them to understand better, enjoy the reading process and read faster and more in a flexible environment. Thus, the BL modality could represent an option to practice ER due to its flexible system to put in practice the strategies described above and promote reading not only in-class time but also outside it. In the following lines, the BL will be described.

\section{Blended learning modality}

Working with this modality is gaining growth in Mexico since the Education is becoming spread through either the distant or blended modality as well as in other parts of the world.

Different studies mention the effectiveness and advantages of working with BL modality to promote reading proficiency, ER and important components in the leaning process. For instance, Guzer and Caner (2014) said that BL helped the education field to develop motivation, critical and flexible thinking and avoid abandoning school.

Garrison \& Vaughan (2008) affirm that BL promotes meaningful and worthy learning experiences. Furthermore, Hew and Cheung (2014) suggested that BL helps students to foster communication among themselves since they share information at any time thanks to the asynchronous virtual space, which implies that they develop cognitive strategies to understand what they are reading.

Another crucial feature of working with this modality is that it allows students to be enrolled in a great variety of tasks for growing their reading comprehension what could mean that the BL can help students to develop ER meaningfully (Arancon, Barcena and Arus, 2012; Alseweed, 2013).
Last but not least, Kengwee and Kidd (2010, p. 6) claim that in online courses like BL, the cognitive tasks require "responding to questions; editing questions and responses; thinking, reasoning, and analyzing information; and helping students to engage in rehearing and retrieving information in the process of delivering online courses". Then, BL could be considered as a medium to complement the learning reading process, to solve doubts that could not be done due to the available time, predesigned programs and lesson plans in onsite sessions, to balance and continue developing activities that contribute to the ER process that demands the use of those cognitive strategies.

\section{Extensive reading in a blended learning modality}

There is too much research that supports the positive idea of practicing ER in the BL modality due to its results, motivation and affordable cost. At this point, Diel (2019) mentions that the means of socialization of readings among teenagers is digital. On one hand, according to Elley (2000) who has accomplished studies of ER for many years, claims that students who read extensively for long periods, improve their reading comprehension abilities by getting meaningful comprehension.

Then, BL modality turns into a powerful tool to do so since it let students to read at any time a variety of texts as well as to share what they read with others in the platform and prove their understanding with the different tasks where they have to put in practice some strategies like activation, prediction, inference, summary, graphic representation of their knowledge, questioning and monitoring.

On the other hand, Grabe (2014) indicates that there are some crucial elements to engage students in extensive reading, which match the advantages that BL learning provides students when practicing reading.

They are:

1. Provide many attractive reading materials.

2. Provide time for free reading or SSR in class.

3. Create many opportunities for all types of reading, in class and out.

4. Have a good class library.

5. Read interesting material for students. 
6. Find out what students like to read and why.

7. Create ways to interest students in reading topics.

8. Let students read magazines, comic books, newspapers in class.

9. Talk about what you read and why that material is interesting to you.

10. Have students share and recommend reading material. (p.16)

Additionally, in order to have a successful and meaningful reading comprehension as well as ER program, it is necessary to involve both students and teachers in the process, make ER part of the teaching timetable, have an up-dated variety of interesting materials at appropriate levels and according to students'learning styles and suitable ways to assess the reading process. Taking into account the previous requirements, Poon (2012, p. 144) states that BL "ensures a good mix of methods which can suit the needs of different learning styles and learning preferences". Then, BL could promote extensive reading.

\section{Methodology}

Having in mind that in this study the subjects' perception is going to be measured, it is necessary to define it. According to Oviedo in Remuzgo (2019), it is an essential process for mental functioning that is related to other functions such as learning, memory, and thinking.

Then, to analyze this phenomenon, a quantitative descriptive study was accomplished with a Likert-scale questionnaire as an instrument to know about students' perceptions towards the asseveration if blended learning modality promotes extensive reading.

Respect to the second research question that looks for if the subjects considered having meaningful reading comprehension when working in a blended learning modality to promote extensive reading, a Toefl examination was applied before and after working in a blended learning modality since it was considered that students' perceptions are not enough to prove if they get meaningful comprehension. Then, a standard test was done to have a valid parameter to prove the second research question.
Besides, taking into account Hernández, Fernandez and Baptista (2008) a quantitative methodology was chosen so that through quantitative results the research questions and hypotheses could be proven to accurately establish behavioral patterns in the sample.

\section{Design}

Talking about the design, this study was crosssectional because the questionnaire was applied only once. However, the second instrument (Toefl test) was applied twice to compare the results between them and know if the students' perceptions agreed with the students' reading comprehension level and prove if extensive reading is promoted in the blended learning platform in a meaningful way.

\section{Sample}

The population was made of 30 subjects; then, the whole population became the sample of the study.

They shared characteristics like:

All of them have taken English classes in the Faculty of Languages, BUAP for one year and a half and are in the same level of English.

They are enrolled in the blended learning modality. The online sessions were in the moodle platform 24 hours during seven days a week and on-site sessions twice a week one hour in each one respectively.

\section{Instrument}

To answer the two research questions and prove the two hypotheses, two instruments were applied. The former consists of a questionnaire with a Likert scale of agreement with 10 dimensions and 30 items. (See table 1). It is worthy to mention that its validity was done with the SPSS software getting a bilaterally of 0.001 .

The main objective of this instrument was to look for information that confirms if the blended learning modality promotes extensive reading according to the students' perceptions. To do so, it was necessary to have items (in this case three for each dimension. See Table 1) that highlight first of all, if reading comprehension was developed because there could not be extensive reading without reading comprehension.

FLORES-GONZÁLEZ, Norma. Promoting extensive reading in a blended learning modality: Students' perceptions. Journal of Teaching and Educational Research. 2019 
Then, the questionnaire has four sections and was designed regarding McEwan, 2007; Martín in Banda, 2019, Day, 2004 who point out that cognitive strategies, which are promoted in a BL modality if the tasks are pedagogically designed, enhance reading comprehension. Indeed, if cognitive strategies are practicing constantly during the reading act, they can foster $\mathrm{ER}$, the main objective of this research.

Section 1. It deals with the Cognitive strategies of attention, perception, and memory in Pre Reading to get ER in a BL modality.

Section 2. It figures out information about the fostering of extensive reading in the BL platform during the reading process by using the cognitive strategies of attention, perception, and memory.

Section 3. It shows students' perceptions about the use of cognitive strategies of attention, perception, and memory after reading so that ER could be developed in the BL modality.

Section 4. It inquires if students think that the BL modality facilities the enhancement of ER through its main characteristics like ER in short periods with pleasure, variety of reading genres, books, and tasks, and synchronous and asynchronous virtual environment.

The latter was a Toefl test, a pre-designed examination (only the reading comprehension score was analyzed).

This instrument was applied to answer the second research question and probe the second hypothesis because it was necessary to complement the students' perceptions and confirm or refute if when they worked in a blended learning modality to promote extensive reading, they had meaningful reading comprehension. Therefore, their scores would indicate if after developing ER in the $\mathrm{BL}$ modality, their reading comprehension were meaningfully in terms of proficiency in reading.

\section{Procedure of data collection}

First of all, the Toefl examination was applied to know the reading comprehension level of the subjects before starting working on the moodle platform.
After, the subjects worked in the moodle platform to promote their extensive reading meaningfully.

Finally, the Toefl examination was carried out again to contrast them with the first scores and prove the hypotheses, and at the same time, the questionnaire was applied to know students' perceptions about promoting ER in the BL modality.

\section{Analysis of data}

The data gotten was analyzed according to the research questions:

\begin{tabular}{|c|c|c|c|}
\hline Variable 1 & \multicolumn{3}{|c|}{ Instrument: Questionnaire } \\
\hline $\begin{array}{l}\text { Research } \\
\text { question } 1\end{array}$ & Strategy & $\begin{array}{l}\text { Questions that } \\
\text { highlight the } \\
\text { use of these } \\
\text { dimensions: }\end{array}$ & Items \\
\hline \multirow[t]{10}{*}{$\begin{array}{l}\text { Does } \\
\text { blended } \\
\text { learning } \\
\text { modality } \\
\text { promote } \\
\text { extensive } \\
\text { reading? }\end{array}$} & $\begin{array}{l}\text { Cognitive } \\
\text { strategies of } \\
\text { attention, } \\
\text { perception, and } \\
\text { memory in } \\
\text { Pre-reading }\end{array}$ & $\begin{array}{l}\text { Activating in } \\
\text { groups }\end{array}$ & $1,8,18$ \\
\hline & \multirow{3}{*}{$\begin{array}{l}\text { Cognitive } \\
\text { strategies of } \\
\text { attention, } \\
\text { perception, and } \\
\text { memory while } \\
\text { reading }\end{array}$} & Inferring & $2,12,19$ \\
\hline & & $\begin{array}{l}\text { Monitoring- } \\
\text { clarifying }\end{array}$ & $7,10,21$ \\
\hline & & $\begin{array}{l}\text { Representing } \\
\text { the knowledge } \\
\text { with Graphic } \\
\text { organizers }\end{array}$ & $4,14,16$ \\
\hline & \multirow{3}{*}{$\begin{array}{l}\text { Cognitive } \\
\text { strategies of } \\
\text { attention, } \\
\text { perception, and } \\
\text { memory after } \\
\text { reading }\end{array}$} & $\begin{array}{l}\text { Questioning } \\
\text { classmates }\end{array}$ & $6,11,17$ \\
\hline & & $\begin{array}{l}\text { Summarizing } \\
\text { for others }\end{array}$ & $3,13,20$ \\
\hline & & $\begin{array}{l}\text { Sharing } \\
\text { information }\end{array}$ & $5,9,15$ \\
\hline & $\begin{array}{l}\text { Blended } \\
\text { learning } \\
\text { modality } \\
\text { facilities to } \\
\text { promote ER }\end{array}$ & $\begin{array}{ll}\text { ER in short } \\
\text { periods } \\
\text { pleasure }\end{array}$ & $22,25,28$ \\
\hline & & $\begin{array}{lr}\text { Variety } & \text { of } \\
\text { reading genres, } \\
\text { books, and tasks }\end{array}$ & $24,27,29$ \\
\hline & & $\begin{array}{l}\text { Synchronous } \\
\text { and } \\
\text { asynchronous } \\
\text { virtual } \\
\text { environment }\end{array}$ & $23,26,30$ \\
\hline
\end{tabular}

Table 1 Model of analysis. (McEwan, 2007; Martín in Banda, 2019, Day, 2004) 


\begin{tabular}{|l|l|}
\hline \multicolumn{2}{|c|}{ Variable 2 } \\
\hline Research question 2 & Toefl exam \\
\hline $\begin{array}{l}\text { Do subjects consider } \\
\text { having Toefl proficiency test } \\
\text { reading comprehension } \\
\text { when working in a }\end{array}$ & (only the reading score) \\
blended learning & \\
modality? & \\
\hline
\end{tabular}

Table 2 Model of analysis to measure meaningful reading

\section{Findings}

Taking into consideration that the objective of the study is to know if the use of blended learning modality promote extensive reading based on students' perceptions as well as to know if they consider having a meaningful reading comprehension when working with it at the Bachelor in Teaching English at BUAP, the following results are presented:

\section{Variable 1}

Does blended learning modality promote extensive reading?

To answer this research question, characterize the subjects' perceptions and prove the hypothesis: Extensive reading is promoted in a blended learning modality, the questionnaire was divided into three phases:

1) Cognitive strategies of attention, perception, and memory that were applied in the BL modality to promote extensive reading in the Pre-reading stage

2) Cognitive strategies of attention, perception, and memory that were applied in the BL modality to promote extensive reading while the reading stage

3) Cognitive strategies of attention, perception, and memory that were applied in the BL modality to promote extensive reading after the reading stage.

Subjects' perceptions about promoting extensive reading in a blended learning modality in the Pre-reading stage

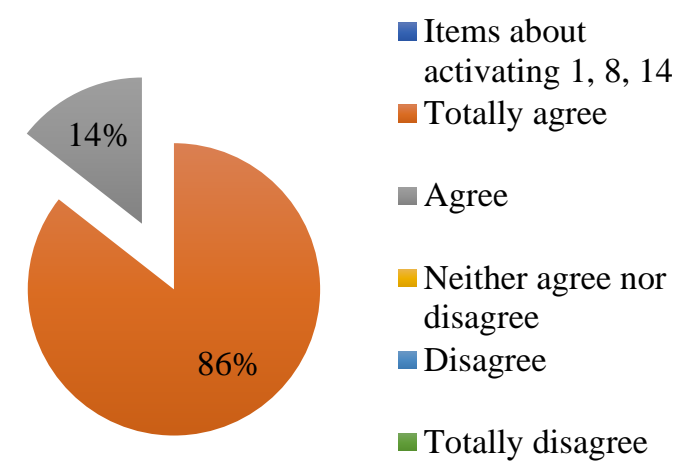

Graphic 1 Promoting ER in the BL modality with the Activating strategy

$86 \%$ of the subjects totally agreed and $14 \%$ agreed that by applying the activating strategy, they grasped the knowledge and was easier to read more in less time.

They perceived that the BL modality pushed them to practice a lot with this strategy in the different tasks they had to answer, which was another way to know they understood what they were reading. Then, they assumed that ER was promoted by BL modality thanks to its pedagogical designed that includes the activating reading strategy which belongs to the cognitive strategy of attention, perception, and memory in the Pre-reading phase. This documented what McEwan (2007) and Martín in Banda, (2019) claims about the ER process.

\section{Subjects' perceptions about promoting extensive reading in a blended learning modality while Reading}

For this section, three dimensions were taken into account in the pedagogical designed of the BL modality to promote the ER: inferring, monitoring-clarifying, and representing the knowledge with graphic organizers,

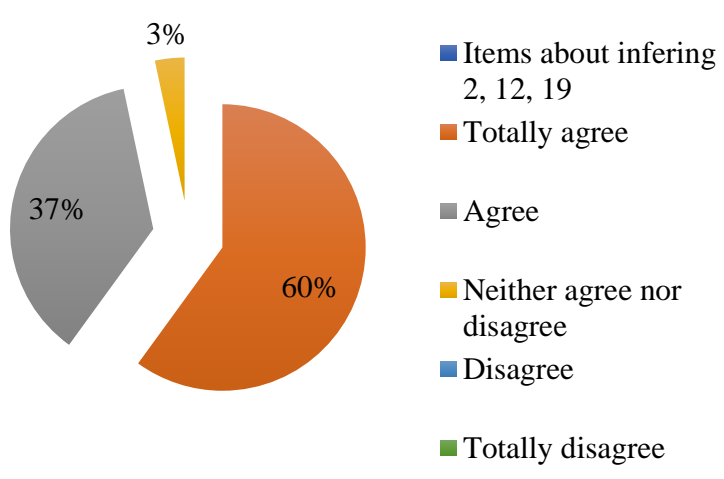

Graphic 2 Promoting ER in the BL modality with the inferring strategy 
$60 \%$ of the subjects agreed, $37 \%$ agreed and $3 \%$ neither agreed nor disagreed with the idea that inferring strategy promotes ER in the BL modality.

They also expressed that due to the inference, they could comprehend more from a text and got into the ER stage fluently and meaningfully.

As can be observed, the majority of the sample perceived that the ER was promoted. This result is confirmed by Guzer and Caner (2014) who stated that BL scrutinizes the teaching and learning of the language skills (like reading) as well as students' critical thinking.

In addition, subjects did what Angulo, Angulo, Cortes, and Sotelo (2019) claimed. They could accomplish relationships between previous knowledge and new knowledge.

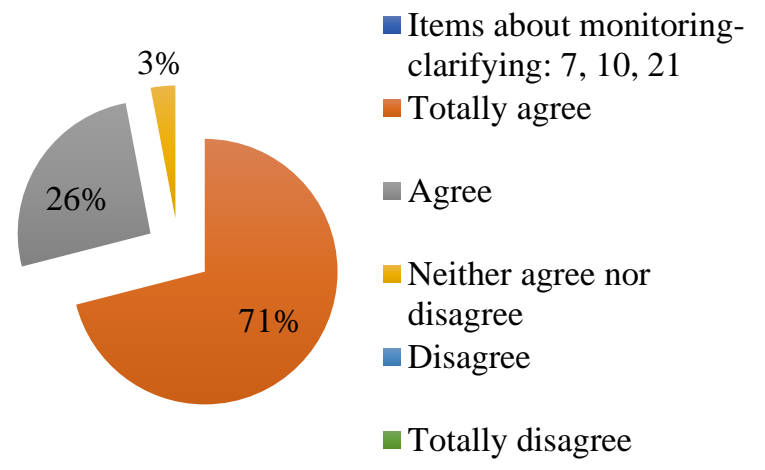

Graphic 3 Promoting ER in the BL modality with the Monitoring-clarifying strategy

$71 \%$ of the sample totally agree while $26 \%$ agreed and 3\% neither agreed nor disagreed. In general, the sample regarded this strategy as a useful tool to be successful in the ER, especially because the teacher's help was available at any moment through his guidance, questioning role and reader's model as Day (2002) described.

Another important point was that the subjects realized this strategy assisted them in restoring the meaning and identified extracts from the texts that they did not understand. Finally, they became aware of its benefits and found it as a way to ask questions, restate their meaning and monitor their reading comprehension process to read faster and more.

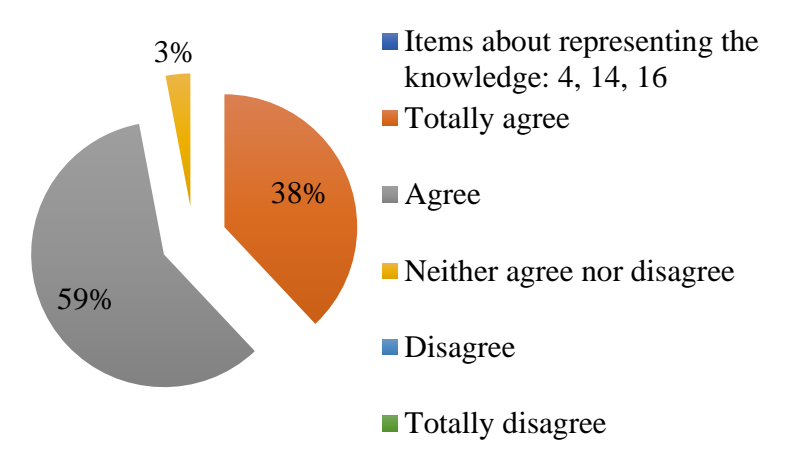

Graphic 4 Promoting ER in the BL modality with the representing the knowledge strategy (Graphic organizers)

Graphic representation of the knowledge is a strategy that gave subjects assistance to keep track of their thoughts, structure, and meaning of what they read since they were reading about different topics and a variety of books (ER) so that later, they could express and share information with others. Regarding this, 59\% of the subjects agreed and 38\% agreed, which means that more than half of the sample perceived this as a positive way not only to foster their reading comprehension but also to develop their ER process.

Besides, subjects liked the graphic organizer samples that were included in the pedagogical design of the BL. In fact, they mentioned that those visual aids were attractive because of their colorfulness, easy to follow to grasp the knowledge and represent their understanding of the readings, and the most important, graphic organizers were really practical to read the Toefl test passages faster and have better comprehension as mentioned by Day and Bamford (2002).

\section{Subjects' perceptions about promoting extensive reading in a blended learning modality after Reading}

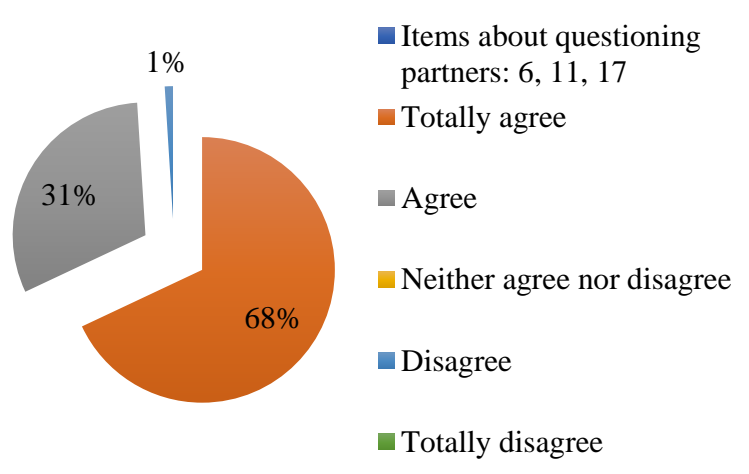

Graphic 5 Promoting ER in the BL modality with the Questioning classmates strategy 
Thanks to the BL modality, subjects could question their classmates virtually very frequently. Even though $1 \%$ neither agreed nor disagreed, $68 \%$ of the sample totally agreed and $68 \%$ agreed with the idea that this strategy allowed them both to flourish extensive reading and communicative competence because it pushed them to speak in English.

Another important aspect is that they perceived this way of working as keeping high levels of motivation while reading a lot a variety of books.

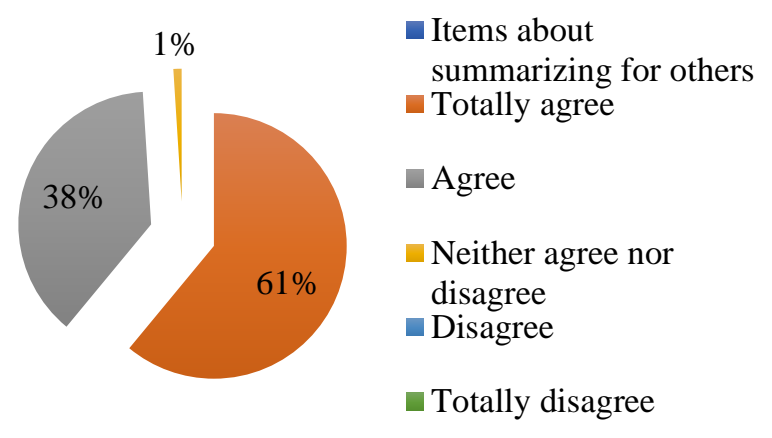

Graphic 6 Promoting ER in the BL modality with the Summarizing strategy

Concerning it, $61 \%$ totally agreed and $38 \%$ agreed that the summarizing strategy in the BL modality was viable to get the ER process since it was a powerful tool to recall, comprehend and organize information in a clear way. This subjects' asseveration is related to Aguilar's assertion (2019) about characteristics of summary: clearness, accuracy, and flexibility to get comprehension from a text.

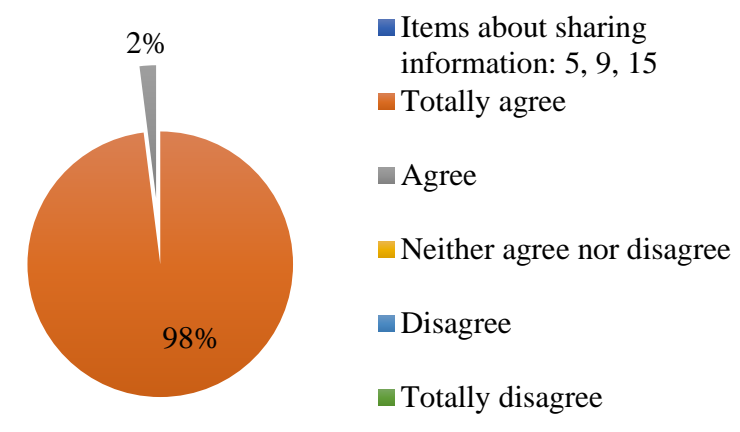

Graphic 7 Promoting ER in the BL modality with the sharing information strategy

About these results, although $2 \%$ neither agreed nor disagreed, $98 \%$ of the sample confirmed that sharing information with others after reading was a valuable experience to increase extensive reading.
Taking into account that extensive reading is directly connected with how much you retain about what you read, subjects regarded this strategy as a perfect one to retain information by sharing what they understood from their reading. Additionally, they gained fluency in their oral production, vocabulary baggage and mastery of the foreign language. Last, they mentioned that while sharing information, they kept highly motivated by listening to the comments about other books that they ended reading them because of their interests and curiosity.

\section{Subjects' perceptions about Blended Learning modality facilities to promote ER}

For this strategy, three dimensions were analyzed, getting 3 items for each one. In the following lines, they will be described.

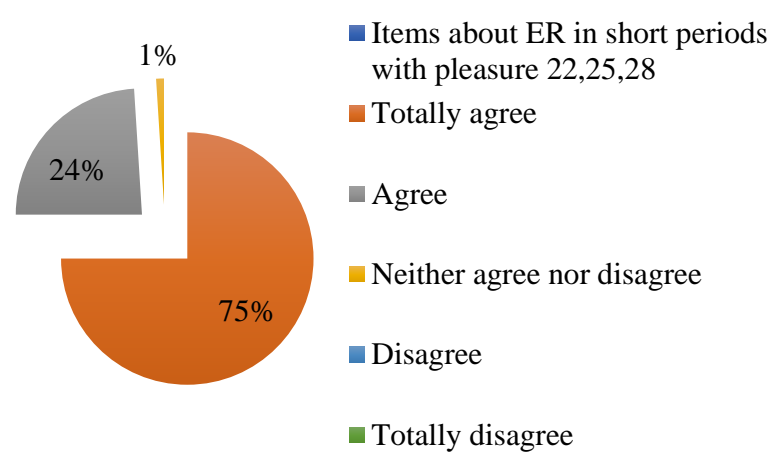

Graphic 8 BL modality facility: ER in short periods with pleasure

$75 \%$ totally agreed, $24 \%$ agreed and $1 \%$ neither agreed nor disagreed that one of the BL facilities was the flexibility to read in considerably short periods big quantities of reading with a high level of pleasure.

This corroborates what Day (2002) claims about the importance of selecting correct reading material for extensive reading by choosing them according to students' interests, needs, and proficiency level to privilege motivation and energy while reading.

Another feature that subjects pointed out was the use of audio recording books. They agreed that this listening material provided help to read faster as well as a model of correct pronunciation, which let them word recognition with different speech rhythms and accents. Moreover, they built up the confidence to produce more natural and authentic speeches, which guided them to master the language when talking about their reading.

FLORES-GONZÁLEZ, Norma. Promoting extensive reading in blended learning modality: Students' perceptions. Journal of Teaching and Educational Research. 2019 


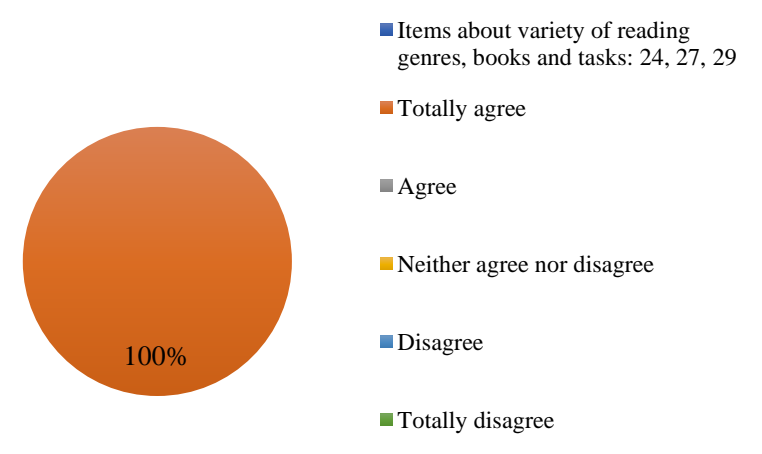

Graphic 9 BL modality facility: Variety of reading genres, books, and tasks

$100 \%$ of the sample totally agreed with the idea of BL modality allowed them to have a variety of reading genders, books and tasks in the same virtual space at low cost, in an attractive way and nice atmosphere, getting as a result extensive and intensive reading.

Another facility was that the extensive reading was done under subjects' control since they did not feel obligated to do it; they did it by pleasure or interest to read it based on some other classmates' comments or descriptions during the virtual sharing book sessions. They said that reading became part of their lives and habits.

In addition, they perceived that by reading this variety of topics, their vocabulary baggage increased considerably as well as their writing style, which was even a higher motivation to continue practicing in $\mathrm{BL}$ modality. Finally, the most important finding in this dimension was that the whole sample agreed that by reading different books and genres, they gained what Hedgcock and Ferris (2009) called knowledge of the other cultures.

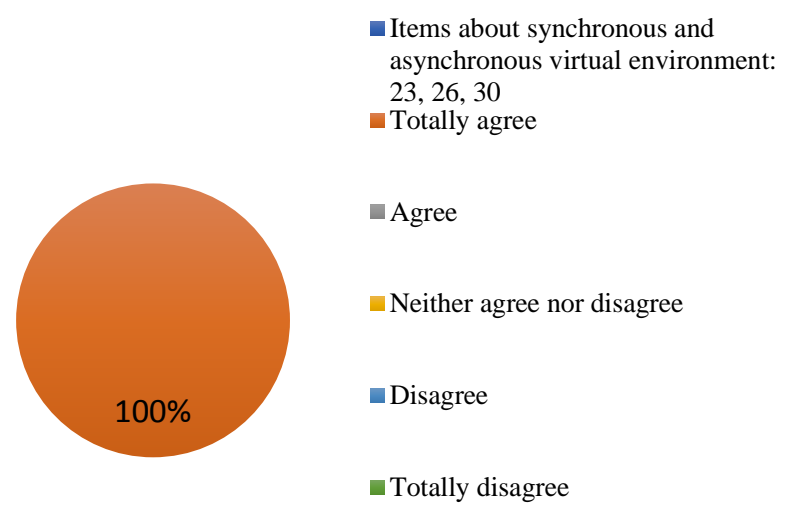

Graphic 10 BL modality facility: Synchronous and asynchronous virtual environment
Another characteristic of the BL modality was its synchronous and asynchronous environment that was perceived as a positive feature by the subjects since $100 \%$ totally agreed with this dimension.

What they liked the most was the flexibility to work at any time and place as well as to be in such an attractive virtual space where they had access to some other tools like digital dictionaries, graphic representation templates, different reading comprehension activities that looked like games, virtual spaces to talk with their classmates and build up assignments collaboratively. They developed a sense of belonging to a community.

These findings corroborated what ay and Bamford (2002) mentioned about the importance of selecting materials according to students' level because they granted to read quickly and with high levels of comprehension. As been seen, the students' perceptions were positive and the first hypothesis was proven since they assure that BL modality does promote ER.

\section{Variable 2}

As in any reading comprehension process, it is necessary to check students' understanding of reading as well as their progress. These can be done through different devices like tests, quizzes or even just to assess whether the reading has been done or not. That is why in this study, it was decided to apply a Toefl examination (only the reading section was taken into account) before starting working in the moodle platform to promote the extensive reading and after finishing working with it with the purpose to prove the second hypothesis of this study and the students' perceptions described above described.

The second research question is:

Do subjects consider having meaningful reading comprehension when working in a blended learning modality to promote extensive reading? The table shows the different score subjects got after working in the BL modality with the pedagogical design that was mentioned before. 


\begin{tabular}{|c|c|c|c|}
\hline Subject & $\begin{array}{l}\text { Toefl score } \\
\text { before } \\
\text { practicing } \\
\text { ER in the } \\
\text { BL modality }\end{array}$ & $\begin{array}{c}\text { Toefl score } \\
\text { after } \\
\text { practicing } \\
\text { ER in the } \\
\text { BL modality }\end{array}$ & $\begin{array}{l}\text { Difference } \\
\text { in points }\end{array}$ \\
\hline 1 & 340 & 420 & 80 \\
\hline 2 & 360 & 490 & 130 \\
\hline 3 & 400 & 500 & 100 \\
\hline 4 & 380 & 490 & 110 \\
\hline 5 & 325 & 450 & 125 \\
\hline 6 & 360 & 500 & 140 \\
\hline 7 & 380 & 490 & 110 \\
\hline 8 & 350 & 480 & 130 \\
\hline 9 & 300 & 450 & 150 \\
\hline 10 & 320 & 420 & 100 \\
\hline 11 & 340 & 430 & 90 \\
\hline 12 & 360 & 450 & 90 \\
\hline 13 & 340 & 450 & 110 \\
\hline 14 & 320 & 430 & 110 \\
\hline 15 & 380 & 490 & 110 \\
\hline 16 & 320 & 440 & 120 \\
\hline 17 & 340 & 460 & 120 \\
\hline 18 & 380 & 500 & 120 \\
\hline 19 & 360 & 440 & 80 \\
\hline 20 & 300 & 420 & 120 \\
\hline 21 & 310 & 430 & 120 \\
\hline 22 & 340 & 450 & 110 \\
\hline 23 & 380 & 500 & 120 \\
\hline 24 & 340 & 480 & 140 \\
\hline 25 & 300 & 490 & 190 \\
\hline 26 & 200 & 380 & 180 \\
\hline 27 & 320 & 430 & 110 \\
\hline 28 & 300 & 450 & 150 \\
\hline 29 & 340 & 480 & 140 \\
\hline 30 & 380 & 490 & 110 \\
\hline
\end{tabular}

Table 3 Comparable table of the Toelf reading scores to measures the meaningfulness of the promotion of ER in the BL modality

The results characterized the subjects' perceptions as identifying the blended learning modality like a suitable learning resource to promote extensive reading as well as another technology-based instructional delivery environment with special attributes that empower meaningful reading-learning experiences by using cognitive strategies of attention, perception, and memory in the prereading, while reading and after reading stages with their respective dimensions.

Moreover, table 3 shows important results because all the subjects improved their reading proficiency meaningfully. The least improved 80 points in comparison with his previous result and the highest improved 190 points respectively.

\section{Conclusions}

As can be seen in the finding section, the hypotheses:

$\mathrm{H} 1$ : extensive reading is promoted in a blended learning modality according to students' perceptions
$\mathrm{H} 2$ : When working in a blended learning modality to promote extensive reading, students have meaningful reading comprehension, were corroborated.

This study implies that effective ER could be fostered in platforms only if pedagogical designs are taken into account according to students' level, interests, and needs.

Even though, this requires a lot of investment time, selection and design of the resources, the benefits and advantages for students make up for those efforts.

Considering this study, some decisions could be taken too, like for example, to include these types of programs into the curriculum to flourish such an important skill like this in the foreign language learning process.

Additionally, this study showed that although some subjects had a low reading proficiency level, they improved by practicing ER in BL modality thanks to its activation process, learning styles variety and flexibility of the platform to read at their own rhythm.

At the same time, a relationship was identified between ER and BL modality in terms of a positive effect on reading comprehension level.

\section{Further research}

It is suggested to apply the same study with a different methodology for example: with a mixed methodology (quantitative and qualitative) to have more complete data to analyze, and of course, more complete study. Another option could be a pre and post-treatment test with experimental design and control and experimental group.

\section{References}

Aguilar, L. (2019). Estrategias de aprendizaje y logros de aprendizaje en el área de ciencias sociales en estudiantes del cuarto grado de educación secundaria de la institución educativa José Carlos Mariátegui del distrito de Orurillo, provincia de Melgar, región Puno. (Tesis de Licenciatura). Universidad Católica los Ángeles. Chimbote, Perú. 
Alseweed, M.A. (2013). Students' achievement and attitudes toward using traditional learning, blended learning, and virtual classes learning in teaching and learning at the University level. Studies in Literature and Language, 6(1), 65-73.

Angulo, W.F., Angulo, E.A., Cortes, D. M., Sotelo, N. (2019). Comprensión Lectora En Estudiantes De Grado Tercero en la Institución Educativa Rural Mixta "La Humildad" Municipio de Barbacoas - Departamento de Nariño. (Tesis de Maestría). Universidad Santo Tomás. Primer Claustro Universitario de Colombia. San Juan de Pasto, Colombia.

Arancon, P. R., Barcena, E., Arus, J. (2012). A novel approach for the development of communicative competence in English in a blended learning context. Journal of Language Teaching and Research, 3 (2), 256-272.

Banda, Z. (2019). Diseño de un sistema de estrategias cognitivas de atención, percepción y memoria para mejorar la capacidad de la comprensión lectora en el área de comunicación en los estudiantes 2do grado de educación secundaria de la Institución Educativa Ciro Alegría Santa Rosa. (Tesis de Maestría). Universidad Nacional Pedro Ruiz Gallo, Perú.

Day, R., Bamford, J. (1998). Extensive Reading. England: Cambridge University Press.

Day, R., Bamford, J. (2002). Extensive Reading Activities for Teaching Language, Cambridge University Press.

Diel, M. (2019). Lecturas, pantallas y adolescentes lectores. Uruguay: Universidad ORT.

Elley, W. (2000). The potential of book flooding for raising literacy levels. International Review of Education, 46, 233-255.

Garrison, D. R., Vaughan, N. D. (2008). Blended Learning in Higher Education: Framework, Principles, and Guidelines. San Francisco, CA: Jossey-Bass.

Grabe, W. (2014). Key Issues in L2 Reading Development. Proceedings of 4th CELC Symposium for English Language TeachersSelected Papers, 8-18. National University of Singapore.
Guzer, B., Caner, H. (2014). The past, present and the future of blended learning: An in-depth analysis of literature. Procedia- Social and Behavioral Science, 116, 4596-4603.

Hedgcock, J. S., Ferris, D. R. (2009). Teaching Readers of English: Students, Texts and Contexts. New York: Routledge

Hernández, R., Fernández, C., Baptista, P. (2008). Metodología de la Investigación. México: Mc Graw-Hill.

Hew, K. F., Cheung, W. S. (2014). Using Blended -Learning: Evidence based practices. Singapore: Springer.

Instituto Nacional de Estadística y Geografía. (2018). Disminuye la población lectora en México: módulo de lectura (molec) 2018. México: INEGI.

Kengwee. J., Kidd, T. (2010). Towards best practice in online learning and teaching in Higher Education. J Online Learn and Teach. 6. 533-541.

McEwan, E.K., (2007). 40 Ways to Support Struggling Readers in Content Classrooms. Lodon: Corwin Press.

Poon, J. (2012). Use of blended learning to enhance the student learning experience and engagement in property education. Property Management, 30(2), 129-156.

Remuzgo, A. (2019). Percepción de los egresados sobre el proceso enseñanza aprendizaje en una universidad privada: desde una perspectiva cuali-cuantitativa. (Tesis de doctorado). Universidad Nacional Mayor de San Marcos Universidad del Perú. Decana de América, Perú.

Renandya, W. A., Jacobs, G. M. (2002). Extensive reading: Why aren't we all doing it? In J. C. Richards \& W. A. Renandya (Eds.), Methodology in language teaching: An anthology of current practice. New York: Cambridge University Press. 